\title{
HUBUNGAN KADAR S100B SERUM TERHADAP LUARAN KLINIS NEUROLOGIS PASIEN STROKE ISKEMIK AKUT
}

\author{
RELATIONSHIP OF SIOOB SERUM WITH NEUROLOGIC CLINICAL \\ OUTCOME IN ACUTE ISCHEMIC STROKE PATIENTS \\ Windri Kartikasari, * Retnaningsih, * Amin Husni*
}

\section{ABSTRACT}

Introduction: Biomarker levels of S100B serum have a correlation with the degree of damage to brain tissue so that it can be used as a marker to determine the clinical outcomes of patients with acute ischemic stroke.

Aims: To determine the association of S100B serum levels 72 hours of onset to NIHSS score changes in acute ischemic stroke patients. Determine the association of confounding factors that affecting NIHSS score changes and S100B serum levels.

Method: This research is an analytic observational study with prospective cohort design. Subjects were patients diagnosed with acute ischemic stroke who meet the inclusion criteria. This study used bivariate and multivariate analysis.

Result: There was a significant relationship between S100B serum levels and changes in the NIHSS score. There was a significant relationship between BMI status and NIHSS score changes. There was a significant relationship between $S 100 B$ serum levels with age $\geq 65$ years, with hypertension, and with dyslipidemia to NIHSS score changes. There was a significant relationship between S100B serum levels in subject $\geq 65$ years old with hypertension to NIHSS score changes. There was no significant relationship between S100B serum levels with dyslipidemia, hypertension, and diabetes mellitus to NIHSS score changes.

Discussion: In this study, S100B serum levels were significant correlated with NIHSS score changes in acute ischemic stroke patients. There was a correlation between $S 100 B$ serum levels with age $\geq 65$ years, hypertension, dyslipidemia. In subjects with age $\geq 65$ years old and hypertension, S100 serum levels was significantly associated with NIHSS score changes in acute ischemic stroke patients.

Keywords: Confounding factors, NIHSS score changes, S100B serum

\section{ABSTRAK}

Pendahuluan: Kadar penanda serum S100B berkorelasi dengan derajat kerusakan jaringan otak sehingga dapat digunakan sebagai petanda untuk mengetahui luaran klinis pasien stroke iskemik akut.

Tujuan: Mengetahui hubungan kadar S100B serum 72 jam pasca-onset terhadap perubahan skor NIHSS pada pasien stroke iskemik akut dan faktor-faktor menjadi perancu.

Metode: Penelitian ini merupakan penelitian observasional analitik dengan pendekatan kohort prospektif. Subjek adalah pasien yang didiagnosis stroke iskemik akut pertama kali. NIHSS dikatakan membaik jika perubahan skor antara hari ke-7 dan 3 perawatan $\geq 2$. Analisis bivariat dilanjutkan dengan analisis multivariat dilakukan antara NIHSS dengan kadar S100B dan faktor-faktor perancu lainnya.

Hasil: Didapatkan hubungan bermakna antara kadar S100B serum dengan perubahan skor NIHSS. Didapatkan hubungan bermakna antara status BMI dengan perubahan skor NIHSS. Terdapat hubungan bermakna antara kadar S100B serum dengan umur $\geq 65$ tahun, dengan hipertensi, dan dengan dislipidemia terhadap perubahan skor NIHSS. Terdapat hubungan bermakna antara kadar S100B serum pada subjek umur $\geq 65$ tahun dengan hipertensi terhadap perubahan skor NIHSS. Tidak terdapat hubungan antara kadar S100B serum dengan dislipidemia, hipertensi, dan DM terhadap perubahan skor NIHSS.

Diskusi: Terdapat hubungan antara kadar S100B serum terhadap perubahan skor NIHSS pasien stroke iskemik akut. Terdapat hubungan antara kadar S100B serum dengan dengan umur $\geq 65$ tahun, hipertensi, dan dislipidemia. Pada umur $\geq 65$ tahun dengan hipertensi, kadar S100B berhubungan terhadap perubahan skor NIHSS pasien stroke iskemik akut.

Kata kunci: Faktor-faktor perancu, perubahan skor NIHSS, S100B serum

*Bagian Ilmu Penyakit Saraf FK UNDIP/RSUP Dr. Kariadi Semarang. Korespondensi: windrikartikasari@gmail.com.

\section{PENDAHULUAN}

Penyumbatan aliran darah otak yang terjadi pada stroke iskemik akan menurunkan energi yang diperlukan untuk mempertahankan metabolisme normal sel-sel otak. Sel-sel otak yang iskemik ini tidak dapat mengendalikan pelepasan ion melalui membran sel dan menyebabkan akumulasi ion kalsium intraseluler. Akumulasi kalsium intraseluler 
akan menginduksi proses apoptosis dan mengaktifkan berbagai macam enzim yang berakibat pada kerusakan sel-sel otak. ${ }^{1}$

Cedera otak pada stroke iskemik menyebabkan berbagai perubahan patologis mengakibatkan kerusakan neuronal yang mempengaruhi neuron dan sel glia pada jaringan otak yang diikuti terjadinya pelepasan biomarker neuronal dan sel glia yang spesifik seperti protein S100B, glial fibrillary acidic protein (GFAP), myelin basic protein (MBP), dan neuron-specific enolase (NSE). ${ }^{2}$ Penelitian eksperimental telah menunjukkan bahwa iskemia serebral menginduksi perubahan sitoskeleton dan mengaktivasi gen terkait apoptosis, yang mengakibatkan reaksi morfologis neuron, astrosit, oligodendrosit, dan mikroglia. Salah satu konsekuensi proses hipoksia ini adalah inflamasi otak, yang selanjutnya berkontribusi terhadap kematian sel dan injury otak pada stroke akut. ${ }^{3}$

Protein S100B sebagai salah satu penyusun sitoskeleton jaringan otak akan dilepaskan setelah terjadi kerusakan neuron dan glia dan kerusakan sawar darah otak yang terjadi akibat kaskade iskemia pada stroke iskemik. Kadar penanda S100B serum memiliki korelasi dengan derajat kerusakan jaringan otak sehingga dapat digunakan sebagai petanda untuk mengetahui luaran klinis pasien stroke iskemik akut. Indikator yang dapat diandalkan ini sangat bermanfaat untuk perencanaan dan menentukan strategi pengobatan yang tepat dan memungkinkan klinisi untuk memberi informasi tentang prognosis yang akurat kepada pasien dan keluarga. ${ }^{2,4-5}$

Derajat beratnya stroke yang menggambarkan luaran klinis neurologis diukur dengan skor National Institutes of Health Stroke Scale (NIHSS). NIHSS merupakan salah satu alat pemeriksaan yang dapat mengukur defisit neurologis penderita stroke secara terukur yang dapat diandalkan dan valid dalam memprediksi luaran klinis stroke. ${ }^{6}$

Terdapat beberapa faktor yang berperan penting pada stroke iskemik fase akut yang dapat digunakan untuk memperkirakan luaran klinis stroke meliputi usia, jenis kelamin, diabetes melitus (DM), hipertensi, dislipidemia, obesitas, serta volume dan ukuran infark. ${ }^{7-13}$

\section{TUJUAN}

Penelitian ini bertujuan untuk mengetahui hubungan kadar S100B serum dalam 72 jam onset terhadap luaran klinis neurologis menggunakan skor NIHSS, dengan menganalisis faktor-faktor perancu yang mempengaruhi perubahan skor NIHSS dan kadar S100B serum.

\section{METODE}

Penelitian ini merupakan penelitian observasional analitik dengan pendekatan kohort prospektif. Subjek penelitian adalah pasien stroke iskemik akut yang dirawat di Instalasi Rawat Inap RSUP dr. Kariadi dan RSUD dr. Soeselo, Slawi dari bulan Agustus-November 2018 dengan kriteria inklusi pasien stroke iskemik akut pertama kali onset $<72$ jam yang telah dibuktikan dengan pemeriksaan CT scan kepala polos dan setuju mengikuti penelitian. Kriteria eksklusi meliputi stroke iskemik berulang, cedera kepala dalam 3 bulan terakhir, perdarahan subaraknoid, tumor otak, gangguan psikiatri, infeksi saraf pusat, dan pasien stroke iskemik yang dilakukan rtPA.

Data primer diperoleh dari pasien stroke iskemik akut menggunakan kuesioner yang terdiri atas data demografi, faktor risiko, pemeriksaan fisik, pemeriksaan laboratorium berupa sampel darah vena, pemeriksaan CT scan kepala, penilaian klinis neurologis dengan NIHSS pada hari onset ke 3 dan ke 7. Perbaikan ditandai dengan penurunan skor NIHSS $\geq 2$ poin. Data berskala numerik diuji normalitasnya dengan Saphiro-Wilk. Uji beda antara variabel berskala numerik dan kategorik dilakukan uji independent t-test bila sebaran data normal dan uji non-parametrik Mann-Whitney bila sebaran data tidak normal. Analisis bivariat variabel berskala kategori tabel $2 \times 2$ dilakukan dengan uji $\chi 2$, uji Fisher dan uji Kolmogorov-Smirnov 2 sampel. Nilai $\mathrm{p}$ dianggap bermakna jika $\mathrm{p}<0,05$. Hasil analisis bivariat dengan $\mathrm{p} \leq 0,25$ dianalisis lebih lanjut dengan uji multivariat regresi logistik untuk mengetahui variabel yang berpengaruh terhadap perubahan skor NIHSS yang sudah dikategori.

Pasien yang masuk dalam kriteria inklusi diminta bukti persetujuan secara tertulis dengan membubuhkan tanda tangan pada lembaran informed consent. 


\section{HASIL}

Penelitian ini melibatkan 42 subjek pasien stroke iskemik akut. Distribusi subjek berdasarkan karakteristik demografik, klinis, data mengenai S100B serum dan NIHSS subjek dapat dilihat pada Tabel 1.

Penelitian ini mendapatkan hubungan bermakna antara kadar S100B serum terhadap perubahan skor NIHSS (Tabel 2).

Analisis bivariat dilakukan pada usia, jenis kelamin, DM, hipertensi, dislipidemia, ukuran infark,
Tabel 2. Uji Hubungan antara Kadar S100B terhadap Perubahan NIHSS $(n=42)$

\begin{tabular}{cccc}
\hline \multirow{2}{*}{ Variabel } & \multicolumn{2}{c}{ Perubahan NIHSS } & \multirow{2}{*}{$\mathbf{p}$} \\
\cline { 2 - 3 } & Membaik & $\begin{array}{c}\text { Tidak } \\
\text { Membaik }\end{array}$ & \\
\hline Kadar S100B & 18 & 24 & $0,014^{*} *$ \\
\hline
\end{tabular}

*Hubungan bermakna $\mathrm{p}<0,05$; ${ }^{\ddagger}$ Mann-Whitney. NIHSS: National Institute of Health Stroke Scale.

dan status BMI terhadap perubahan skor NIHSS pasien (Tabel 3). Didapatkan hubungan antara status BMI dengan perubahan skor NIHSS pasien $(p=0,025)$.

Tabel 1. Karakteristik Subjek Penelitian $(n=42)$

\begin{tabular}{|c|c|c|c|}
\hline \multirow{3}{*}{ Karakteristik } & \multicolumn{2}{|c|}{ Perbaikan NIHSS } & \multirow{3}{*}{$\begin{array}{c}\text { Rerata } \pm \text { SB } \\
\text { Median (Min-Maks) }\end{array}$} \\
\hline & Ya $(n=18)$ & Tidak $(n=24)$ & \\
\hline & n (\%) & n $(\%)$ & \\
\hline $\begin{array}{l}-\quad<65 \text { tahun } \\
-\quad>65 \text { tahun }\end{array}$ & $5(27,8)$ & $12(50)$ & $60,50(17-84)$ \\
\hline \multicolumn{4}{|l|}{ Jenis Kelamin } \\
\hline - Laki-laki & $8(44,4)$ & $15(62,5)$ & \\
\hline - Perempuan & $10(55,6)$ & $9(37,5)$ & \\
\hline \multicolumn{4}{|l|}{ Diabetes Melitus } \\
\hline - Ya & $2(11,1)$ & $5(20,8)$ & \\
\hline - Tidak & $16(88,9)$ & $19(79,2)$ & \\
\hline \multicolumn{4}{|l|}{ Hipertensi } \\
\hline - $\mathrm{Ya}$ & $16(88,9)$ & $16(66,7)$ & \\
\hline - Tidak & $2(11,1)$ & $8(33,3)$ & \\
\hline \multicolumn{4}{|l|}{ Dislipidemia } \\
\hline - Ya & $16(88,9)$ & $20(83,3)$ & \\
\hline - Tidak & $2(11,1)$ & $4(16,7)$ & \\
\hline \multicolumn{4}{|l|}{ Status BMI } \\
\hline - Obese & $11(61,1)$ & $22(91,7)$ & \\
\hline - Non-obese & $7(38,9)$ & $2(8,3)$ & \\
\hline \multicolumn{4}{|l|}{ Ukuran Infark } \\
\hline - Lakuner tunggal & $3(16,7)$ & $1(4,2)$ & \\
\hline - Lakuner multipel & $14(77,8)$ & $18(75)$ & \\
\hline - Teritorial tunggal & $1(5,6)$ & $3(12,5)$ & \\
\hline - Teritorial multipel & $0(0)$ & $0(0)$ & \\
\hline - Campuran & $0(0)$ & $2(8,3)$ & \\
\hline Perubahan Skor NIHSS & $18(42,8)$ & $24(57,2)$ & \\
\hline Kadar S100B Serum (ng/L) & & & $894,5(194,2-4.097,2)$ \\
\hline
\end{tabular}

Min-Maks: minimum-maksimum; NIHSS: National Institute of Health Stroke Scale; SB: simpangan baku. 
Tabel 3. Uji Hubungan antara Perubahan Skor NIHSS dengan Variabel Perancu $(n=42)$

\begin{tabular}{|c|c|c|c|}
\hline \multirow{2}{*}{ Variabel } & \multicolumn{2}{|c|}{ Perubahan NIHSS } & \multirow{2}{*}{ p } \\
\hline & Membaik & Tidak Membaik & \\
\hline \multicolumn{4}{|l|}{ Usia } \\
\hline - $<65$ tahun & $13(72,2)$ & $12(50)$ & $0,147^{¥}$ \\
\hline - $\geq 65$ tahun & $5(27,8)$ & $12(50)$ & \\
\hline \multicolumn{4}{|l|}{ Jenis Kelamin } \\
\hline - Laki-laki & $8(44,4)$ & $15(62,5)$ & $0,245^{¥}$ \\
\hline - Perempuan & $10(55,6)$ & $9(37,5)$ & \\
\hline \multicolumn{4}{|c|}{ Diabetes Melitus } \\
\hline - $\mathrm{DM}$ & $2(11,1)$ & $5(20,8)$ & $0,679^{£}$ \\
\hline - Bukan DM & $16(88,9)$ & $19(79,2)$ & \\
\hline \multicolumn{4}{|l|}{ Hipertensi } \\
\hline - Ya & $16(88,9)$ & $16(66,7)$ & $0,147^{£}$ \\
\hline - Tidak & $2(11,1)$ & $8(33,3)$ & \\
\hline \multicolumn{4}{|l|}{ Dislipidemia } \\
\hline - $\mathrm{Ya}$ & $16(88,9)$ & $20(83,3)$ & $0,685^{\mathfrak{f}}$ \\
\hline - Tidak & $2(11,1)$ & $4(16,7)$ & \\
\hline \multicolumn{4}{|c|}{ Ukuran Infark } \\
\hline $\begin{array}{l}\text { - Lakuner } \\
\text { tunggal }\end{array}$ & $3(16,7)$ & $1(4,2)$ & $0,970^{\epsilon}$ \\
\hline $\begin{array}{l}\text { - Lakuner } \\
\text { multipel }\end{array}$ & $14(77,8)$ & $18(75)$ & \\
\hline $\begin{array}{l}\text { Teritorial } \\
\text { tunggal }\end{array}$ & $1(5,6)$ & $3(12,5)$ & \\
\hline - Campuran & $0(0)$ & $2(8,3)$ & \\
\hline - Status BMI & & & \\
\hline - Non-obese & $11(61,1)$ & $22(91,7)$ & $0,025^{£ *}$ \\
\hline - Obese & $7(38,9)$ & $2(8,3)$ & \\
\hline
\end{tabular}

*Signifikan $(\mathrm{p}<0,05)$; ${ }^{\ddagger}$ Mann-Whitney; ${ }^{*}$ Pearson Chi-square; ${ }^{t}$ Fisher's exact; ${ }^{\epsilon}$ Kolmogorov-Smirnov 2 sampel. NIHSS: National Institute of Health Stroke Scale.

Analisis multivariat menunjukkan bahwa secara statistik usia kurang dari 65 tahun merupakan faktor risiko untuk perbaikan skor NIHSS sebesar 15,334 kali (rasio Odds $/ \mathrm{RO}=3,398, \mathrm{p}=0,112$ ). Jenis kelamin perempuan merupakan faktor risiko untuk perbaikan skor NIHSS sebesar 1,171 kali dengan $\mathrm{RO}=0,257, \mathrm{p}=0,079$. Subjek tanpa hipertensi merupakan faktor risiko untuk perbaikan skor NIHSS sebesar 19,671 kali $(\mathrm{RO}=3,009, \mathrm{p}=0,250)$. Variabel yang paling berpengaruh terhadap perbaikan skor NIHSS pasien stroke iskemik akut adalah status BMI non-obese dengan kekuatan hubungan yaitu $\mathrm{RO}=0,096, \mathrm{p}=0,018$ (Tabel 4).
Analisis statistik mendapatkan nilai cut off kadar S100B serum kurang dari 773ng/L merupakan

Tabel 4. Uji Regresi Logistik Berdasarkan Perubahan NIHSS

\begin{tabular}{lccc}
\hline \multicolumn{1}{c}{ Variabel } & $\mathbf{p}$ & RO & IK 95\% \\
\hline Usia & 0,112 & 3,398 & $0,753-15,334$ \\
Jenis kelamin & 0,079 & 0,257 & $0,056-1,171$ \\
Hipertensi & 0,250 & 3,009 & $0,460-19,671$ \\
Status BMI & $0,018^{*}$ & 0,096 & $0,014-0,672$ \\
Kadar S100B & 0,139 & 1,001 & $0,9997-1,001$ \\
\hline
\end{tabular}

RO: rasio Odds; IK: interval kepercayaan.

faktor risiko untuk perbaikan skor NIHSS sebesar 1,001 kali (RO=1,001, p=0,139) (Gambar 1).

Analisis lebih lanjut dilakukan untuk mengetahui hubungan antara kadar S100B serum dengan 1 variabel perancu yaitu umur $\geq 65$ tahun, DM, hipertensi, dan dislipidemia terhadap perubahan skor NIHSS. Didapatkan bahwa kadar S100B serum pada subjek dengan umur $\geq 65$ tahun $(p=0,027)$, dengan hipertensi $(p=0,014)$, dan dengan dislipidemia $(p=0,011)$ berhubungan signifikan terhadap perubahan skor NIHSS (Tabel 5).

Uji hubungan antara kadar S100B serum dengan 2 variabel perancu didapatkan bahwa kadar S100B serum pada subjek umur $\geq 65$ tahun dengan hipertensi $\quad(p=0,019)$ berhubungan signifikan terhadap perubahan skor NIHSS. Kadar S100B serum pada subjek umur $\geq 65$ tahun dengan dislipidemia tidak berhubungan dengan perubahan skor NIHSS $(\mathrm{p}=0,066)$. Adapun kadar S100B pada subjek umur $\geq 65$ tahun dengan DM tidak dapat dianalisis karena hanya didapatkan 2 subjek dengan umur $\geq 65$ tahun pada kelompok NIHSS membaik saja dan tidak didapatkan subjek berumur $\geq 65$ tahun dengan DM pada kelompok yang tidak mengalami perbaikan skor NIHSS. Kadar S100B serum pada subjek DM dengan hipertensi, dan dengan dislipidemia juga tidak berhubungan dengan perubahan skor NIHSS (Tabel 5).

Uji hubungan antara kadar S100B serum dengan 3 variabel perancu yaitu dislipidemia, hipertensi, dan DM terhadap perubahan skor NIHSS tidak didapatkan hubungan antara kadar S100B terhadap perubahan skor NIHSS pada pasien stroke 


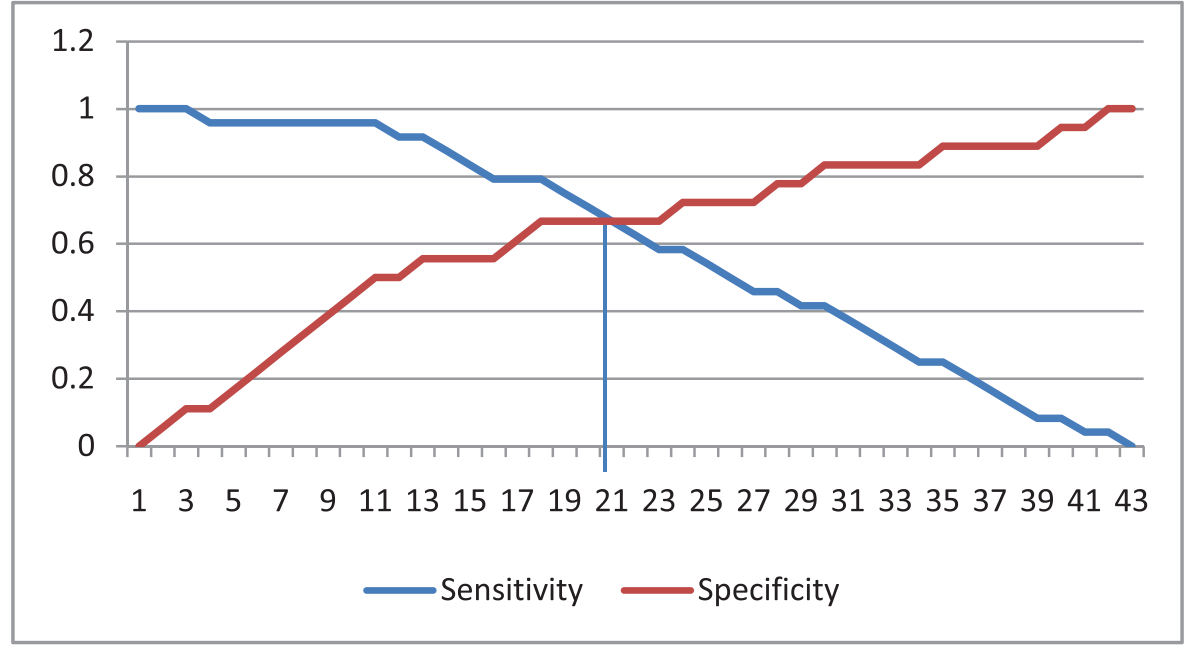

Keterangan Kurva

\begin{tabular}{ccccccc}
\hline AUC & Asymp. Sig. & \multicolumn{2}{c}{ IK 95\% } & Sensitivitas & Spesifisitas & Cut of Point \\
\hline 0,725 & 0,014 & 0,557 & 0,892 & 0,667 & 0,667 & $773 \mathrm{ng} / \mathrm{L}$ \\
\hline
\end{tabular}

Gambar 1. Kurva ROC Cut Off Nilai S100B

Tabel 5. Uji Hubungan antara Kadar S100B Serum dengan Faktor-faktor Perancu terhadap Perubahan NIHSS

\begin{tabular}{|c|c|c|c|c|c|}
\hline \multirow{3}{*}{ Kadar S100B } & \multicolumn{4}{|c|}{ Perubahan NIHSS } & \multirow{3}{*}{$\mathbf{p}$} \\
\hline & \multicolumn{2}{|r|}{ Membaik } & \multicolumn{2}{|c|}{ Tidak Membaik } & \\
\hline & n $(\%)$ & Kadar (ng/L) & n $(\%)$ & Kadar (ng/L) & \\
\hline Umur $\geq 65$ Tahun & $5(29,4)$ & $264,1(194,2-1753,2)$ & $12(70,6)$ & $944,75(243-4097,2)$ & $0,027 *$ \\
\hline - $\mathrm{DM}$ & $2(28,6)$ & $948,35 \pm 584,00$ & $5(71,4)$ & $1103,82 \pm 708,95$ & $0,797^{\S}$ \\
\hline - Hipertensi & $16(50)$ & $299,1(194,2-3571,8)$ & $16(50)$ & $1072,95(311,6-4097,2)$ & $0,014 *$ \\
\hline - Dislipidemia & $16(44,4)$ & $312,8(194,2-2519)$ & $20(55,6)$ & $1168,3(243-4097,2)$ & $0,011^{* *}$ \\
\hline \multicolumn{6}{|l|}{ Umur $\geq 65$ Tahun } \\
\hline - $\mathrm{DM}$ & $0(0)$ & - & $2(100)$ & $381,35(243-519)$ & - \\
\hline - Hipertensi & $5(38,5)$ & $264,1(194,2-1753,5)$ & $8(61,5)$ & $1610,4(519,7-4097,2)$ & $0,019 *$ \\
\hline - Dislipidemia & $4(28,6)$ & $944,75(194,2-1753,5)$ & $10(71,4)$ & $944,75(243-4097,2)$ & $0,066^{*}$ \\
\hline \multicolumn{6}{|l|}{ DM } \\
\hline - Hipertensi & $2(40)$ & $948,35 \pm 584,00$ & $3(60)$ & $1113,53 \pm 537,34$ & $0,765^{\S}$ \\
\hline - Dislipidemia & $2(28,6)$ & $312,8(194,2-2519)$ & $5(71,4)$ & $1103,82 \pm 708,95$ & $0,797 \S$ \\
\hline $\begin{array}{l}\text { Dislipidemia, } \\
\text { Hipertensi, DM }\end{array}$ & $2(40)$ & $948,3 \pm 584$ & $3(60)$ & $1113 \pm 537,3$ & 0,765 \\
\hline
\end{tabular}

*Signifikan $(\mathrm{p}<0,05) ;{ }^{\S}$ Independent $t$-test; ${ }^{*}$ Mann Whitney. NIHSS: National Institute of Health Stroke Scale.

iskemik akut dengan dislipidemia, hipertensi, dan DM $(p=0,765)$ (Tabel 5).

\section{PEMBAHASAN}

Hasil penelitian ini menunjukkan bahwa tidak terdapat hubungan antara jenis kelamin terhadap luaran klinis neurologis. Hasil ini berbeda dengan penelitian Yu dkk yang mendapatkan bahwa perempuan lanjut usia dengan stroke iskemik akut memiliki derajat keparahan stroke yang lebih berat pada 3 dan 12 bulan pascastroke. ${ }^{14}$

Dari penelitian ini tidak didapatkan hubungan antara usia terhadap luaran klinis neurologis. Penelitian ini sesuai dengan penelitian Shresta dkk 
yang menyatakan bahwa umur tidak berpengaruh signifikan terhadap luaran klinis neurologis pasien stroke iskemik akut. Dari penelitian Shresta dkk didapatkan umur tidak berpengaruh secara signifikan dalam analisis bivariat tetapi analisis multivariat regresi logistik memperlihatkan umur sebagai prediktor yang baik dari luaran stroke iskemik. ${ }^{15}$

Navis dkk dalam penelitiannya yang membandingkan luaran stroke iskemik dan transient ischemic attack pada populasi dewasa dan geriatri mendapatkan bahwa pasien dengan usia 80 tahun ke atas memiliki komorbiditas lebih banyak, mendapatkan terapi tissue plasminogen activator atau trombektomi, dan memiliki luaran yang lebih buruk. ${ }^{7}$

Hasil penelitian ini menunjukkan tidak terdapat hubungan antara DM terhadap luaran klinis neurologis. Penelitian oleh Nacu yang membandingkan karakteristik klinis termasuk faktor risiko, komorbiditas, luaran jangka pendek, dan angka mortalitas jangka panjang pada pasien stroke iskemik dengan dan tanpa diabetes. Penelitian tersebut mendapatkan bahwa luaran fungsional jangka pendek yang lebih buruk dan mortalitas jangka panjang yang meningkat pada pasien dengan DM dan infark serebral. ${ }^{9}$

Penelitian ini mendapatkan hasil yang berbeda dengan literatur yang menyebutkan bahwa DM berhubungan dengan luaran klinis neurologis pasien stroke iskemik akut. Kondisi hiperglikemia akan berkontribusi terhadap luaran yang buruk pada pasien stroke iskemik akut. Hiperglikemia yang terjadi pada stroke iskemik akut merupakan mekanisme respons terhadap stres metabolik yang mengakibatkan kerusakan neuronal jaringan otak yang lebih berat yang akan memengaruhi luaran klinis. Meskipun demikian terdapat banyak faktor lain selain hiperglikemia yang lebih dominan dalam mempengaruhi luaran klinis pasien stroke iskemik akut.

Penelitian ini mendapatkan tidak terdapat hubungan antara hipertensi terhadap luaran klinis neurologis. Penelitian yang dilakukan oleh Nayak dkk di India memperlihatkan perbandingan luaran klinis pasien stroke iskemik akut dengan dan tanpa hipertensi. Angka kematian dan angka ketergantungan pasien stroke iskemik akut pada saat keluar dari rumah sakit adalah sama antara pasien dengan dan tanpa hipertensi. Sedangkan luaran jangka panjang pada 12 bulan dan 18 bulan menunjukkan rasio angka ketergantungan yang lebih tinggi pada pasien stroke iskemik akut dengan hipertensi bila dibandingkan dengan pasien tanpa hipertensi. ${ }^{10}$

Hipertensi sering kali menyertai serangan stroke akut. Hipertensi pada stroke dapat memicu dan memperburuk edema pada jaringan otak yang iskemik sehingga akan memperburuk luaran klinis. ${ }^{17}$ Hasil penelitian ini tidak sesuai dengan penelitian sebelumnya. Hal ini mungkin dikarenakan keterbatasan penelitian kami tidak memonitor tekanan darah subjek secara kontinu sedangkan luaran klinis neurologis dipengaruhi oleh variasi kenaikan tekanan darah pada subjek yang terjadi pada hari-hari pertama onset stroke iskemik. ${ }^{17}$

Pada penelitian ini tidak didapatkan hubungan antara kondisi dislipidemia terhadap luaran klinis neurologis. Suatu penelitian berskala besar di Cina yang dilakukan oleh Xu Tian dkk yang melibatkan 1.568 subjek mendapatkan kadar kolesterol total serum dan kolesterol HDL berhubungan signifikan dengan luaran pasien stroke iskemik akut. ${ }^{11}$

Hasil penelitian ini tidak sesuai dengan penelitian sebelumnya yang menyatakan bahwa dislipidemia berhubungan dengan luaran klinis neurologis pasien stroke iskemik akut. Dislipidemia telah diketahui sebagai faktor risiko luaran buruk yang dihubungkan dengan penyakit kardiovaskular. Namun studi-studi sebelumnya mengenai efek kadar lipid serum terhadap luaran stroke masih diperdebatkan. Beberapa studi mengungkap kadar kolesterol total yang tinggi berhubungan dengan luaran stroke iskemiknamun studilainnya menemukan tidak terdapat hubungan antara kadar kolesterol total dengan luaran yang buruk. Suatu parameter baru yaitu rasio antara trigliserid dan kolesterol HDL berhubungan signifikan dengan penurunan kondisi neurologis dini dan perbaikan klinis setelah stroke iskemik akut. ${ }^{18}$ Pada penelitian ini peneliti hanya menghubungkan kondisi dislipidemia secara umum dengan luaran stroke iskemik akut sehingga hal ini mungkin memengaruhi hasil dari penelitian ini. 
Hasil penelitian ini menunjukkan bahwa terdapat hubungan signifikan antara status BMI terhadap luaran klinis neurologis. Penelitian ini sejalan dengan penelitian sebelumnya yang menyebutkan BMI berhubungan dengan perubahan luaran klinis stroke iskemik akut berdasarkan skor NIHSS. Obesitas merupakan faktor risiko independen stroke dan peningkatan BMI telah dihubungkan dengan penyebab kematian pada populasi umum. ${ }^{19}$

Peran obesitas masih diperdebatkan hingga saat ini, obesitas paradoks telah ditegaskan dalam berbagai studi yang menunjukkan luaran yang berbeda-beda dan berkurangnya kejadian transformasi hemoragik pada pasien obesitas dengan stroke, sedangkan kondisi obesitas yang ekstrim didapatkan berperan terhadap luaran yang buruk dan tingkat mortalitas. Kim dkk mendapatkan bahwa pasien stroke dengan obese mengalami defisit neurologis yang tidak berat yang menjelaskan adanya obesitas paradoks. ${ }^{20}$ Pada penelitian oleh Bas pasien obese memiliki skor NIHSS awal lebih baik, namun memiliki gejala klinis dan luaran serta risiko terjadi transformasi hemoragik atau kematian yang sama antara pasien obese dan non-obese. ${ }^{21}$ Sarikaya dkk, yang meneliti pengaruh obesitas terhadap luaran klinis stroke setelah trombolisis intravena mendapatkan bahwa obesitas merupakan faktor prediktor independen luaran klinis yang buruk diukur dengan mRS dan mortalitas. Perbedaan luaran pasti disebabkan faktor lain yang lebih sering terjadi di rumah sakit seperti komplikasi atau waktu pemulihan yang lebih lama. Obesitas dan overweight berhubungan dengan luaran fungsional jangka pendek yang lebih baik setelah stroke iskemik akut. ${ }^{22}$

Dari penelitian didapatkan tidak ada hubungan antara luas infark terhadap luaran klinis neurologis. Penelitian Alemam mendapatkan bahwa ukuran infark merupakan salah satu faktor yang berpengaruh terhadap luaran pasien stroke iskemik yang diukur dengan NIHSS. Didapatkan luaran stroke iskemik yang buruk pada subjek dengan ukuran infark $>3 \mathrm{~mm}$, sedangkan luaran yang baik didapatkan pada subjek dengan ukuran infark $<1,5 \mathrm{~mm} .{ }^{23}$ Hasil penelitian ini tidak sesuai dengan penelitian sebelumnya yang menyatakan bahwa ukuran infark berhubungan dengan luaran klinis neurologis pasien stroke iskemik akut. Hal ini mungkin dikarenakan lokasi infark lebih dominan mempengaruhi luaran stroke bila dibandingkan faktor ukuran infark. Lokasi infark sangat berpengaruh terhadap disabilitas neurologis yang terjadi pada subjek, di mana lokasi infark pada area eloquent tentu akan mengakibatkan gejala klinis lebih berat bila dibandingkan dengan area otak noneloquent. $^{24}$

Penelitian ini mendapatkan hubungan signifikan antara kadar S100B serum dengan luaran klinis neurologis. Hal ini sesuai dengan penelitian Selcuk dkk yang menyatakan bahwa terdapat korelasi antara luaran fungsional pasien yang diukur dengan mRS pada bulan pertama dengan kadar S100B pada hari ketiga onset. ${ }^{25}$

Kadar S100B pada orang normal berkisar antara $0,02-0,15 \mu \mathrm{g} / \mathrm{L}(20-150 \mathrm{ng} / \mathrm{L})$, pada penelitian ini didapatkan seluruh subjek mengalami peningkatan dengan median 894,5 (194,2-4,097,2) dan nilai cut off $<773 \mathrm{ng} / \mathrm{L}$ sebagai prediktor terjadinya perbaikan NIHSS. Berbagai nilai cut off telah muncul untuk mengidentifikasi brain injury pada stroke iskemik dengan menggunakan kadar S100B. Penelitian Selcuk dkk mendapatkan kadar S100B pada subjek pasien stroke iskemik akut dengan nilai median hari pertama $=112,5(51-2815) \mathrm{ng} / \mathrm{L}$, hari ke $3=123(53-$ 2913)ng/L, dan hari ke= 105 (50-2544)ng/L. ${ }^{25}$

Umur merupakan salah satu faktor yang berhubungan dengan kadar S100B. Hal ini sesuai dengan literatur bahwa kadar S100B pada usia 65 tahun ke atas lebih tinggi dibandingkan pasien usia 65 tahun ke bawah. Hubungan umur dengan kadar S100B serum ini dapat memberikan pengaruh terhadap luaran klinis neurologis sehingga pada penelitian ini didapatkan hubungan signifikan antara kadar S100B serum dengan umur $\geq 65$ tahun terhadap luaran klinis neurologis. ${ }^{26}$

Dari penelitian ini didapatkan hubungan signifikan antara kadar S100B dengan hipertensi terhadap luaran klinis neurologis. Hasil ini sesuai dengan penelitian Kheirouri dkk yang mendapatkan kadar S100B lebih tinggi pada pasien dengan hipertensi bila dibandingkan dengan kontrol. ${ }^{27}$ 
Penelitianinimendapatkanhubungansignifikan antara kadar S100B serum dengan dislipidemia terhadap luaran klinis neurologis. Penelitian yang dilakukan oleh Kheirouri dkk terhadap 44 pasien dengan sindrom metabolik dan 44 subjek kontrol mendapatkan kadar S100B yang lebih tinggi secara bermakna pada subjek dengan peningkatan kadar trigliserid. ${ }^{27}$ Dimungkinkan hubungan kadar S100B dengan dislipidemia turut memengaruhi luaran klinis pada subjek pada penelitian ini.

Didapatkan kadar S100B pada subjek dengan umur $\geq 65$ tahun dengan hipertensi berhubungan signifikan terhadap luaran klinis neurologis. Adapun kadar S100B pada subjek umur $\geq 65$ tahun dengan dislipidemia tidak berhubungan terhadap perubahan NIHSS. Demikian juga kadar S100B serum pada subjek DM dengan hipertensi, dan subjek DM dengan dislipidemia tidak berhubungan dengan perubahan NIHSS. Dari penelitian ini tidak didapatkan hubungan bermakna antara kadar S100B dengan dislipidemia, hipertensi dan DM terhadap luaran klinis neurologis subjek. Penelitian Selcuk dkk mendapatkan faktor jenis kelamin, dan penyakit sistemik yang terjadi secara bersamaan seperti $\mathrm{DM}$, hipertensi dan dislipidemia pada pasien stroke iskemik tidak memiliki pengaruh terhadap kadar S100B serum. Pada penelitian ini dengan semakin banyak faktor perancu terhadap kadar S100B yang dianalisis mengakibatkan jumlah sampel semakin mengecil, hal ini tampaknya turut memengaruhi hasil dari penelitian ini.

Penelitian ini memiliki keterbatasan yaitu jarak waktu pengukuran luaran klinis neurologis pada penelitian ini kurang lama, di mana subjek dihitung ulang skor NIHSS setelah 4 hari dari pengukuran awal, waktu pengambilan sampel darah tidak dapat dilakukan secara seragam tepat pada 72 jam dari onset stroke, terapi standar yang diberikan kepada subjek penelitian belum seragam, dan waktu pemeriksaan CT scan kepala hanya dilakukan saat pasien masuk rumah sakit sehingga berpengaruh terhadap ukuran infark yang terlihat.

\section{KESIMPULAN}

Terdapat hubungan signifikan antara kadar S100B serum pada 72 jam onset terhadap perubahan skor NIHSS. Terdapat hubungan signifikan antara status BMI terhadap perubahan skor NIHSS, dengan status BMI non-obese merupakan prediktor dominan terhadap perbaikan NIHSS.

Kadar S100B serum pada subjek dengan umur $\geq 65$ tahun, dengan hipertensi berhubungan signifikan terhadap perubahan NIHSS. Kadar S100B serum pada subjek umur $\geq 65$ tahun dengan dislipidemia dan hipertensi secara bersama-sama berhubungan signifikan terhadap perubahan NIHSS.

\section{DAFTAR PUSTAKA}

1. Endres M, Dirnagil U, Moskowitz MA. The ischemic cascade and mediators of ischemic injury. Handb Clin Neurol. 2009;92:31-41

2. Guo Y, Li P, Guo Q, Shang K, Yan D, Du S, dkk. Pathophysiology and biomarkers in acute ischemic stroke-A review. Trop J Pharm Res. 2014;12(6):1097105.

3. Hjalmarsson $\mathrm{C}$, Bjerke $\mathrm{M}$, Andersson B, Blennow K, Zetterberg H, Aberg ND, dkk. Neuronal and gliarelated biomarkers in cerebrospinal fluid of patients with acute ischemic stroke. J Cent Nerv Syst Dis. 2014;6:51-8.

4. Glushakova OY, Glushakov AV, Miller ER, Valadka $\mathrm{AB}$ HR. Biomarkers for acute diagnosis and management of stroke in neurointensive care units. Brain Circ. 2016;2:28-47.

5. Bonaventura A, Liberale L, Vecchie A, Casula M, Carbone F, Montecucco F, dkk. Update on inflammatory biomarkers and treatments in ischemic stroke update on inflammatory biomarkers and treatments in ischemic stroke. Int J Mol Sci. 2016;17(12):E1967.

6. Kwah LK, Diong J. National Institutes of Health Stroke Scale (NIHSS). J Physiother. 2014;60(1):61.

7. Navis A, Garcia-santibanez R, Skliut M. Epidemiology and outcomes of ischemic stroke and transient ischemic attack in the adult and geriatric population. J Stroke Cerebrovasc Dis. 2019;28(1):84-9.

8. Santalucia P, Pezzella FR, Sessa M, Monaco S, Torgano G, Anticoli S, dkk. Sex differences in clinical presentation, severity and outcome of stroke: Results from a hospital-based registry. Eur J Intern Med. 2013;24(2):167-71.

9. Nacu A, Thomassen L, Fromm A, Bjerkreim A, Andreassen U, Naess H. Impact of diabetes mellitus on 1867 acute ischemic stroke patients. A Bergen NORSTROKE study. J Res Diabetes. 2015;2015(1):1-11. 
10. Nayak AR, Shekhawat SD, Lande NH, Kawle AP, Kabra DP, Chandak NH, dkk. Incidence and clinical outcome of patients with hypertensive acute ischemic stroke: An update from tertiary care center of Central India. Basic Clin Neurosci. 2016;7(4):351-60.

11. Tian X, Tao ZJ, Mei Y, Huan Z, Wen Qing L, Yan $\mathrm{K}$, dkk. Dyslipidemia and outcome in patients with acute ischemic stroke. Biomed Environ Sci. 2014;27(2):106-10.

12. Jang SY, Shin Y, Kim DY, Sohn MK, Lee J, Lee S, dkk. Effect of obesity on functional outcomes at 6 months post-stroke among elderly Koreans: A prospective multicentre study. BMJ Open. 2015;(5):1-7.

13. Asdaghi N, Pearce LA, Nakajima M, Field TS, Bazan C, Cermeno F, dkk. Clinical correlates of infarct shape and volume in lacunar strokes: The secondary prevention of small subcortical strokes trial. Stroke. 2014;45(10):2952-8.

14. Yu C, An Z, Zhao W, Wang W, Gao C, Liu S, dkk. Sex differences in stroke subtypes, severity, risk factors, and outcomes among elderly patients with acute ischemic stroke. Front Aging Neurosci. 2015;7(174):1-6.

15. Shrestha S, Poudel RS, Khatiwada D TL. Stroke subtype, age, and baseline NIHSS score predict ischemic stroke outcomes at 3 months: A preliminary study from Central Nepal. J Multidiscip Healthc. 2015;8:443-8.

16. Bagg S, Pombo AP, Hopman W. Effect of age on functional outcomes after stroke rehabilitation. Stroke. 2016;33:179-85.

17. Semplicini A, Maresca A, Boscolo G, Sartori M, Rocchi R, Giantin V, dkk. Hypertension in acute ischemic stroke. Arch Intern Med. 2003;163:211-6.

18. Deng Q, Wang H, Sun C, Xing F, Zhang H, Zuo
L, dkk. Triglyceride to high-density lipoprotein cholesterol ratio predicts worse outcomes after acute ischaemic stroke. Eur J Neurol. 2017;24(2):283-91.

19. Kase CS, Wolf PA, Seshadri S. Overweight, obesity, and survival after stroke in the Framingham Heart study. J Am Heart Assoc. 2017;6:1-10.

20. Kim Y, Kim CK, Jung S, Yoon BW, Lee SH. Obesitystroke paradox and initial neurological severity. J Neurol Neurosurg Psychiatry. 2015;86(7):743-7.

21. Bas DF, Ozdemir AO. The effect of metabolic syndrome and obesity on outcomes of acute ischemic stroke patients treated with systemic thrombolysis. 2017;383:1-4.

22. Sarikaya H, Elmas F, Arnold M, Georgiadis D BR. Impact of obesity on stroke outcome after intravenous thrombolysis. Stroke. 2011;42(8):2330-2.

23. Alemam AI. Comparative study of the prognosis of ischemic cerebral stroke subtypes. J Neurol Res. 2017;7(4-5):80-4.

24. Munsch F, Sagnier S, Asselineau J, Bigourdan A, Guttmann CR, Debruxelles S, dkk. Stroke location is an independent predictor of cognitive outcome. Stroke. 2016;47(1):66-73.

25. Selcuk O, Yayla V, Cabalar M, Guzel V, Uysal S, Gedikbasi A. The relationship of serum S100B levels with infarction size and clinical outcome in acute ischemic stroke patients. Arch Neuropsychiatry. 2014;51:395-400.

26. Calcagnile O, Holmen A, Chew M, Unden J. S100B levels are affected by older age but not by alcohol intoxication following mild traumatic brain injury. Scand J Trauma Resusc Emerg Med. 2013;21(52):0 6.

27. Kheirouri S, Ebrahimi E, Alizadeh M. Association of S100B serum levels with metabolic syndrome and its components. Acta Med Port. 2018;31(4):201-6. 